\title{
Forest Accountancy Data Networks as a Means for Investigating Small-Scale Forestry: A European Perspective
}

\author{
Walter Sekot $^{1}$ (D)
}

Accepted: 19 May 2017/Published online: 29 May 2017

(C) The Author(s) 2017. This article is an open access publication

\begin{abstract}
Investigating the socio-economics of small-scale forestry is an important issue, small forest holdings making up a considerable share of Europe's forest sector. Private forest enterprises with less than 200 ha represent $34.6 \%$ of the forest area in Germany and 50.4\% in Austria. The large number of small units triggers specific challenges for empirical research. This paper identifies associated problems and highlights the potential as well as the current limitations of accountancy data networks in monitoring the profitability of farm forestry in Germany and Austria. Although there is little hope for establishing an internationally harmonized monitoring scheme or even a European-wide scheme, there is potential for improving the international comparability of existing recording systems and data analysis. National or sub-national initiatives should be designed in such a way that compatibility with other networking activities enhances the potential for analysis. Some of the most urgent research questions in regard to small-scale forestry are equally significant at the international level and clearly call for coordination. Established forest accountancy data networks should be considered one kind of research infrastructure to be utilized for harmonizing investigations.
\end{abstract}

Keywords Economics of farm forestry · Farm accountancy data network (FADN) · Ratio analysis · Harmonization

Walter Sekot

walter.sekot@boku.ac.at

1 University of Natural Resources and Life Sciences, Vienna, Feistmantelstrasse 4, 1180 Vienna, Austria 


\section{Introduction}

Excluding the Russian Federation, almost half of Europe's forests are privately owned (Forest Europe et al. 2011). However, family forests are highly fragmented, consisting of a large number of mostly very small and heterogeneous forest holdings. Thus, small-scale private forestry is indeed an important part of the forest sector across Europe but it poses some challenges in terms of research, policymaking and extension services (Weiss et al. 2007). Empirical research at the level of individual enterprises is a valuable approach for analyzing the economics of forestry. National forest inventories and agricultural censuses document many characteristics of the forests as well as the ownership structure within the forest sector but provide no information on issues such as profitability and efficiency. Some European countries, especially those of the DACH-region (Germany, Austria and Switzerland), maintain forest accountancy data networks for this purpose (Hyttinen et al. 1997; Sekot et al. 2011).

A forest accountancy data network is a form of infrastructure for empirical economic research. The main components are a sample of enterprises regularly providing accounting data on the one hand and a central database on the other. Such an infrastructure is particularly suitable for monitoring economic indicators and can be used to generate aggregate industry statistics (Sekot 2000; Niskanen and Sekot 2001). Results are of special interest for policy-making and lobbying and may provide an empirical background for research and teaching in forest economics and forest policy. Additionally, the participating forest enterprises or individual owners may benefit from standardized reports and reference data. The established networks differ in terms of their specific goals and settings. Consequently, the results are of different interest for the major categories of stakeholders: managers and owners of forest enterprises, policy-makers and lobbyists, as well as researchers and lecturers. Whereas some networks are specifically designed in order to serve statistical purposes at the policy level, the size and composition of others is driven by the interest of owners or managers who regularly engage in benchmarking exercises.

Brandl et al. (1999, p. 13) stress the potential of the datasets which are accumulated by such networking activities: "Existing, serious information gaps in both the microeconomic and the macroeconomic area, i.e. for the level of the individual enterprise as well as for a whole region, can be filled with the collected and analyzed data." Examples for such extensions to standardized statistics in terms of detailed studies are provided by Brandl (1998) and Hartebrodt et al. (2010). Ultimately, there is the potential of utilizing accountancy networks as an established infrastructure for efficiently conducting specific surveys in regard to additional information and socio-economic variables such as attitudes, behavior or expectations, which are not covered by the standardized data frame (Sekot 2000).

This paper highlights the general challenges associated with the investigation of the economics of small-scale forestry and analyses the concepts and methodology of two accountancy data networks one operated in Germany and one in Austria. Aspects of international comparisons and possible cooperation in research are addressed. 


\section{Forestry in the Context of Agricultural Statistics}

Small-scale private forestry is not adequately represented by the national forest accountancy data networks in Germany or Austria. These refer to larger enterprises of more than 200 or 500 ha respectively. However, the common agricultural policy of the European Union requires a permanent documentation of the agricultural sector on the basis of representative accounting data. According to a specific regulation of the EU, each member state is obliged to establish and maintain a farm accountancy data network (FADN). An FADN is a representative sample of farms which voluntarily adopt a standardized scheme of book-keeping and provide yearly data on the costs and revenues of their agricultural activities. The national FADNs are thus an established, internationally harmonized infrastructure for assessing socio-economic information in rural areas at the level of individual enterprises. In principle, it would be natural to utilize the existing FADNs for investigating the economics of small-scale forestry, the bulk of the sector being associated with farming anyway (Marongiu et al. 2012).

However, the existing FADNs are hardly suitable for this purpose according to the reports of 12 European countries (Hyttinen and Kallio 1998a). Consequently, representative forestry data is not generally available in terms of a byproduct of agricultural statistics. The main reason is simply that an FADN exclusively refers to farms where the size of the agricultural activities is large enough to be considered commercial. Hence, a substantial part of private small-scale forestry is not recognized by the survey framework. Furthermore, data collection is obligatory in regard to agricultural items only, so that costs and revenues associated with any other activity are not necessarily recorded. In practice, all costs and revenues may be considered as agricultural because forestry is usually of marginal significance in the context of commercial farms. Only a few countries such as Austria provide some forestry-specific data as derived from their FADN. An internationally harmonized, systematic recording of forestry costs and revenues within the framework of an FADN would require substantial additional expenditure and would represent only a small and highly specific part of private small-scale forestry.

In Germany, some statistical data on forestry, in particular on fellings, used to be collected for the participants of the FADN with a forest area of between 5 and 200 ha (Nain 1998). However, these data were recorded only optionally and the results were not considered representative. The sampled information was therefore neither analyzed nor published.

The Austrian FADN provides comparatively favorable opportunities for deriving information on forestry. Recognizing the significance of part-time agriculture as well as forestry, the basic network also addresses non-agricultural activities. The sampling frame is not restricted to agriculture and includes pure forest enterprises. In Austria, farm typology even refers explicitly to the proportion of forestry in terms of standard output. In case the share of forestry exceeds one-third of the total standard output, the respective farm is classified as a forest enterprise. Compliance with EU standards for an FADN is achieved by way of a re-classification of the participating farms and by eliminating those elements of the sample which lie outside of the FADN-specific sampling frame (Rebernig 2006). The National 
'Green Report' thus represents $83.9 \%$ of the forest area managed by farmers $(16.1 \%$ are a cut-off associated with very small holdings) and $38.7 \%$ of Austria's total forest area $(61.3 \%$ of the forest area belonging to farm forests with more than 500 ha of woodland and forests with any other type of ownership) (BMLFUW 2016). The data collection covers all areas of operational activities, non-agricultural income and rural households (BMLFUW 2009). All of the 2166 sampling units thus provide data about forest area, labor inputs in the field of forestry, logging and forestry earnings split up into sale of timber, in-house consumption, non-timber revenue and money received from public policies (LBG Austria GmbH 2016).

To utilize the forest economic potential of this representative quota sample effectively, efforts are made to identify the major forestry costs directly or indirectly, thereby allowing at least a rough business accounting (Brenner 2010; Toscani and Sekot 2014, 2015). With the help of newly introduced 'forestry factors', proportional allocation of depreciation, investment and depreciated book values in asset accounting has been implemented, the first results pertaining to the reporting period 2012. Sub-cost categories were established in order to identify forestry-specific external services. Some types of costs, including those of inputs associated with the use of tractors, can be estimated by means of regression analysis. The coefficients of the regression models are derived from the information provided by the small sub-sample of the FADN which makes up the Austrian network of small-scale forestry. Hitherto missing items of cost are estimated by referring to generally available variables including forest area, labor input and cutting volume. Thus, a substantial improvement in forestry statistics can be achieved.

One consequence of the lack of documentation of small-scale forestry at the national level is that a substantial portion of the sector-representing at least a quarter of the forest area in Germany and more than half (54\%) in Austria-is not appropriately accounted for within the framework of sector statistics. In the context of the German Economic Accounts for Forestry (EAF), small-scale forestry is represented by surrogates derived from an investigation of enterprises with more than 200 ha via extrapolation (Dieter 2007). An adjustment acknowledges the differing rates of utilization in terms of fellings per ha by means of an intensity factor'. In Austria, the empirical data provided by the network of farm forests are of some relevance for estimating elements of intermediate consumption for purposes of the EAF. This too is a case of extrapolation associated with an unknown degree of accuracy, the network of farm forests being only a very small purposive sample (Sekot 2007a). These examples of makeshift solutions at least enable the comprehensive documentation of the forest sector and highlight where forest accountancy data networks play a crucial role. Conversely, the set of rules for sector statistics in agriculture and forestry would allow farm forestry to be regarded as a non-separable, non-agricultural activity and hence included in the agricultural accounts (European Communities 2000). Considerable biases and a severe danger of double counting could be triggered by the application of this rule. At the European level it is not clear, whether the agricultural and forestry accounts are harmonized in regard to farm forestry like in Austria. 


\section{Methodological Problems of Monitoring Small-Scale Forestry by Means of Accountancy Data Networks}

The existing national accountancy data networks operating in the forestry sector like those in the DACH-region (Sekot et al. 2011) are typically geared to larger enterprises that continuously supply the market, have an established organizational structure, manage a variety of factors of production including personnel and machinery and rely on an established system of accounting. In contrast, establishing and operating a network devoted to small-scale forestry is associated with specific challenges (Niskanen and Sekot 2001). Not least of which is the fact that the sustainable earnings potential-especially the one of very small ownership unitsonly contributes in a limited way to household income. Accordingly, goals in terms of earnings and profitability are of comparatively little significance whereas inhouse consumption is usually of great importance. Hence, economic indicators and their documentation also tend to be of minor interest from the owners' points of view.

When a particular segment of a sector is to be represented, the population must be operationally defined and the sampling frame has to be attuned to the characteristics of the population and other frame conditions on the one hand and to the specific goals of the investigation on the other. A definition of the target category may refer to alternative concepts. For instance, the following categories overlap to some extent but are not fully compatible. Therefore, it has to be specified explicitly, which of these or any alternatively defined population is to be represented.

- Small-scale forestry: forest ownership with less than 200 ha (e.g. with a cut-off in terms of 5 ha minimum acreage).

- Small-scale private forestry: each small forest, which is not owned by an administrative body.

- Farm forestry: each forest that is managed in the context of an agricultural enterprise.

- Small-scale farm forestry, i.e. farm forests in combination with an upper area limit of e.g. 200 ha.

In practice, the accountancy networks operating in Germany and Austria typically refer to forest management in the context of an agricultural enterprise and thus represent small-scale farm forestry in the sense described above. However, this is only one out of the seven owner categories identified by Hogl et al. (2005). Especially as regards small-scale forestry, there is a general shift of ownership from farmers actively engaged in agriculture towards new or urban proprietors so that increasing shares of small-scale forestry are not documented at all. An investigation in Austria came up with a share of $20 \%$ of 'famer forest owners' with very close connection to agriculture, $22 \%$ of 'urban' and 'forest owners without connection to agriculture' and the remaining 58\% of intermediate categories (Hogl et al. 2005). There is a certain trend in Germany, for some participants to shift from a rural 
towards an urban mentality, but the sample as such does not address absenteeowners specifically.

The population of small farm forests typically consists of a very large number of small holdings. In Austria for instance, $92.8 \%$ of all forest enterprises recognized by the agricultural census are classified as small-scale farm forests. They manage $40.6 \%$ of the total forest area with an average of 10.3 ha per unit. Hence, it would be necessary to rely on large samples of farms as dependent on the level of reliability required in order to obtain statistically sound results, taking into account the great heterogeneity of structural characteristics and activities within this category. The large proportion of fixed costs per survey unit triggers comparatively high cost per hectare associated with a network of small entities (Sekot 2000). Limited funding opportunities lead to small and unbalanced samples which are hardly representative. The results derived from such statistically inferior samples are sensitive to changes in the size or composition of the sample. Ultimately, the potential to identify real economic developments and to draw reliable conclusions may turn out to be a bottleneck of such monitoring endeavors (Sekot 2007b). Focusing the investigation on more homogeneous strata in terms of cut-offs (restrictions in regard to size or any other characteristics) may increase the efficiency of the survey, but reduce the coverage ratio between the sampling frame and the population.

Cost accounting of small businesses tends to be dominated by imputed items such as family labor and in-house consumption. Whereas financial accounting is related to actual transactions, the values per unit underlying such imputations are more or less arbitrary. This may hamper the interpretation and impair the significance of the results.

The general difficulty of adequately accounting for changes in forest assets within the framework of an income statement is exacerbated by the phenomenon of intermittent management in small forests. The yearly cutting volume typically shows an extremely high variability, triggered by calamities such as windblows and a variety of additional external or internal factors. Consequently, it is by no means straightforward to properly address questions of efficiency and economic sustainability in small-scale forestry.

\section{Comparative Analysis of Accountancy Networks Addressing Small-Scale Forestry in Baden-Württemberg (Germany) and Austria}

Monitoring the economic performance of small-scale farm forestry has a long tradition, particularly in Baden-Württemberg (a sub-national initiative at provincial level) and in Austria (in terms of a national approach). Respective accountancy networks have been operated for more than 30 years (Brandl et al. 1999; Brandl 2010; Sekot 2006). These two well-established cases have numerous similarities but also noteworthy differences.

Originally, both networks were purposive samples which focused on rural enterprises with between 5 and 200 ha of forest. Just recently, the sampling frame in Austria has been extended to an upper limit of 500 ha, thereby filling the statistical gap to the network of bigger enterprises. In Baden-Württemberg the sample size of these pure forestry samples with approximately 160 participants is greater than in 
Austria, where between 100 and 120 participants of the nationally extended FADN (comprising also pure forest holdings) keep specific records on forestry costs and revenues. In Austria, the analysis of time series is hampered by repeated changes in the size and composition of the sample. Consequently, the Austrian sample does not represent a true panel in terms of a stable group of participants so that specific analyses are required in order to perform sound comparisons between different periods or to assess economic developments e.g. as regards the profitability of forestry or the efficiency of harvesting operations. The German network is also confronted with fluctuations of the sample, although to a lesser degree. Brandl et al. (1999) report a rate of $69 \%$ of continuous participation over a period of 20 years whereas only $51 \%$ of the current Austrian sample is identical to the one two decades ago. Respective reasons are heterogeneous: Participation being voluntary, farmers may decide to quit or farm characteristics may change so that the farm does not any longer meet the requirements of the sampling frame. In Austria, individual elements of the sample may be skipped for the sake of statistical adjustments of the FADN. In both cases, there are no strict rules for replacing lost elements.

In both networks, the focus of the data collection is on the costs and revenues of forestry activities. In Baden-Württemberg, more than 100 additional non-monetary items characterizing the enterprise (e.g. level of education of the owner, machinery) as well as the forest (e.g. age structure and tree species composition) are documented. This results in substantially better possibilities for analysis and interpretation (Table 1). In contrast, the forest data in Austria comprises less than 20 non-monetary items but are being supplemented by a set of 46 variables originating in the FADN. Until now, however, these additional data are not reflected in the standard reports and are still awaiting statistical analysis.

Both networks are analyzed in regard to regional groupings, although on a merely indicative basis in terms of specific averages without any statistical testing of significant differences. In Baden-Württemberg, the seven original farm forest regions are aggregated to the four main regions addressed by the standard reports. In Austria, only five out of eight main agricultural production regions are represented in the sample. Given the generally low and diverse sampling ratios, these regions are not only documented individually but are further collapsed into 'alpine' and 'nonalpine' categories. In addition to the problem of inconsistent participation (Sekot 2007b), intertemporal comparisons and time series analyses are hampered in the case of Austria by a major modification (in terms of improvements) of the networking activities which occurred between 1998 and 1999. Only from 1999 onwards has the individual data of each participant been stored in a database. Hence, any specific analysis requiring data of individual farms is restricted to the period starting with 1999 .

In forestry, the economic performance indicators of any individual period depend mostly on the level of harvesting activities. Figure 1 shows the results of a special analysis derived from the Austrian network of farm forests, indicating different threshold-levels of harvest as compared to the actual cutting intensity. The breakeven-values are derived from calculations based on the average contribution margin per $\mathrm{m}^{3}$ and quantify the timber output necessary for compensating specified costs. In regard to family income, all costs with the exception of the imputed value of family 
Table 1 Number of non-monetary items covered by the two networks (Sekot 2007c)

\begin{tabular}{lcc}
\hline Category of items & Baden-Württemberg & Austria \\
\hline Typological features (farm descripters) & 15 & 5 \\
Area (e.g. total forest, protective forest, agriculture) & 10 & 9 \\
Forest inventory (e.g. growing stock, increment) & 40 & 0 \\
Labor force (family labor and hired labor) & 15 & 4 \\
Other factors of production (machinery, roads,...) & 27 & 1 \\
Total & 107 & 19 \\
\hline
\end{tabular}

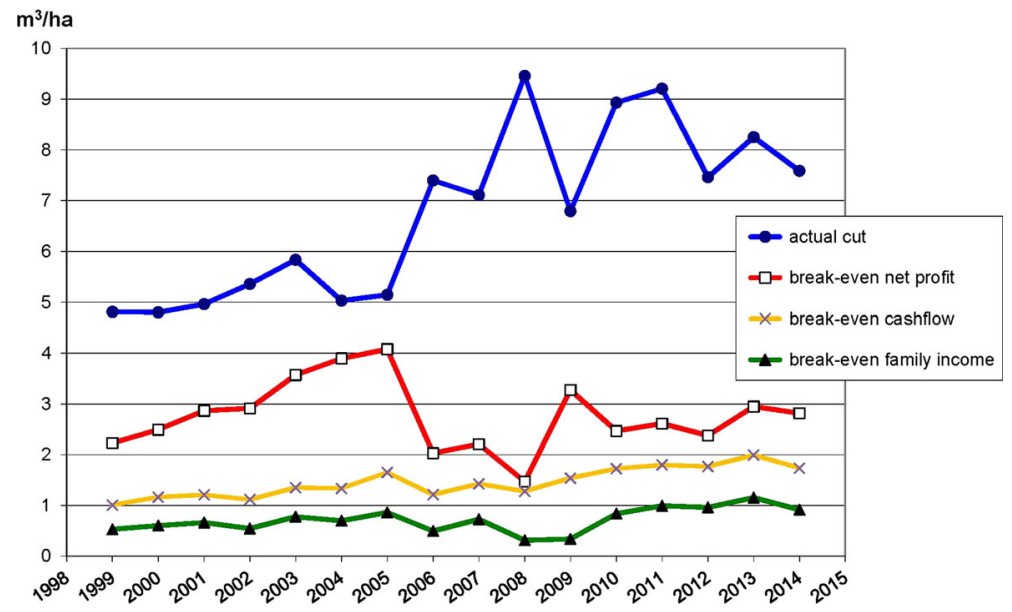

Fig. 1 Development of significant cutting intensities in the Austrian network of farm forests

labor are considered. The break-even for net profit indicates the minimum harvesting intensity required for achieving an income in excess of the value of family labor. Depreciation and unpaid family labor do not affect liquidity and are therefore not considered in regard to cash-flow. Conversely, social security contributions on behalf of the proprietor, which are actual payments beyond the sphere of the forest enterprise, are included in this calculation. Only recently, respective individual results have been integrated into the standard report provided to the participants in order to support the analysis of profit issues also at farm level.

Due to intermittent cutting and sporadic natural disasters, the harvested volume per year varies to a great extent especially for individual small-scale farm forestry operators. This issue is treated differently in the two networks. In Germany, just the ratio of actual cut to the annual allowable cut is provided as additional information at farm as well as aggregate levels (Baron et al. 2001). Whereas this ratio is extremely volatile at the level of the individual enterprise, solid trends can be observed for the whole sample where harsh changes occur only in cases of large scale natural disturbances. Standard reporting in Austria comprises a model 
calculation (Hyttinen et al. 1997). A hypothetical net profit or family income referring to a felling volume which corresponds to the annual allowable cut is derived based on the assumption of a fixed stumpage value per $\mathrm{m}^{3}$ of harvest. Hence, the actual figures can be compared to these hypothetical ones which refer to a sustainable level of utilization, the difference indicating the monetary effects of over- or undercutting on the otherwise disregarded timber balance of the growing stock. Such models are computed separately at farm level as well as for any aggregates. Originally, the annual allowable cut was derived from a standardized forest management plan which was provided without charge to all the participants, a practice still applied in Baden-Württemberg. As this kind of incentive is no longer provided in Austria, a regionally defined level of sustainable production is now being used (Sekot 2011). Consequently, the results are hardly relevant at the farm level but are still of some significance in terms of regional assessments.

Respective model calculations have to be applied prudently. Specific data constellations may occur in small-scale forestry triggering unreasonable results of standard calculations. The increase or decrease as well as the revaluation of stocks of felled timber can dominate the timber revenues in a period where no or hardly any harvest is performed, which may in turn give rise to extreme positive or negative values per cubic meter. In case a constant volume of stock is valued differently and no other timber proceeds occur, the value per $\mathrm{m}^{3}$ as derived by dividing the change in value by the change in volume becomes indefinite. Only recently has it been recognized that such individual outliers may indeed occur in the dataset of small-scale forestry and to what extent group averages can be disrupted when calculated as means of individual ratios. Thus, the 'old approach' in Fig. 2 documents the paradox, that the hypothetical family income at the level of the

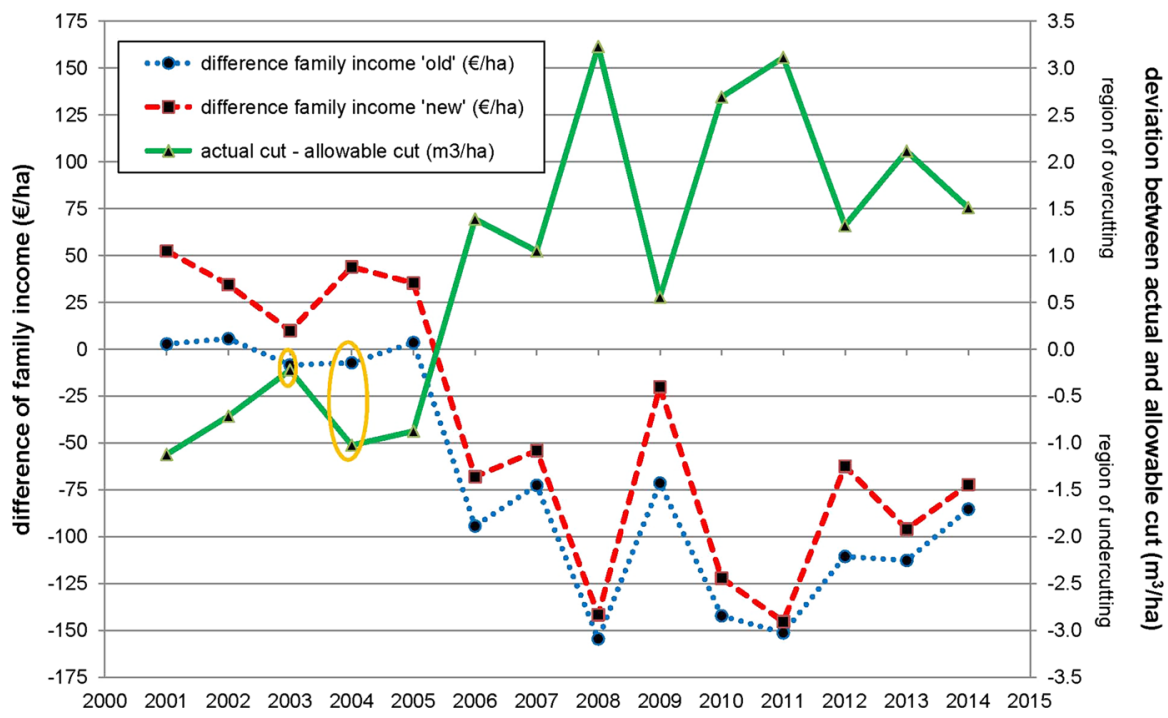

Fig. 2 Differences between family income at the level of the allowable cut and the actual cutting intensity (€/ha, real values with base year of 2014) in relation to over- or undercutting (actual cutallowable cut) 
allowable cut is less than the actual one in periods of undercutting (2003 and 2004, negative differences), indicating the puzzling formal relationship, that a reduction of harvest could in fact increase family income. Meanwhile, this potential bias has been eliminated by a modification of the algorithm for calculating hypothetical results at the aggregate level. Nowadays, the average stumpage value per $\mathrm{m}^{3}$ is calculated on the basis of aggregated figures for volumes and monetary values ('new approach').

\section{Obstacles in Regard to Internationally Comparative Analyses}

Despite the common, decades-long tradition and numerous parallel developments, aspects of international comparability have been studied only sporadically (e.g. Stridsberg and Algvere 1967; Rochot 1984; Brandl 1993; Olischläger 1993; Hyttinen et al. 1997; Hyttinen and Kallio 1998b; Brandl et al. 1999; Sekot et al. 2011; Bürgi et al. 2016). Not even all of these studies refer specifically to accountancy data networks designed for monitoring small-scale farm forestry and there is a tendency to just confront individual results without taking into account any peculiarities. International reference data seem to be of little interest from a managerial perspective. Some forest owners' associations even oppose any harmonization or standardization (Hufnagl 1999). They fear, that any freely agreed upon European standard may ultimately lead to a formal obligation for providing respective data.

In case of established forest accountancy data networks, the adaptation of common standards could disrupt the consistency of time series and thus negatively affect an essential aspect of monitoring. There may even be a deficiency in terms of key figures as demonstrated by the 'DACH-initiative' which investigates the comparability of national networks monitoring bigger forest enterprises in Germany (D), Austria (A) and Switzerland (CH) (Sekot et al. 2011). This example has shown, however, that there is quite a potential for improving the compatibility of results by means of special adjustments and analyses of the existing data without incurring the necessity of fundamental changes in the respective research design. Progress in this respect is arduous and relies on the commitment of key players, international comparisons not being original goals of the national or sub-national networking activities. Only recently, the DACH-initiative further clarified the basis for common definitions, established a new set of primary ratios and decided on a comparison of national developments covering the years 2008-2013 (Bürgi et al. 2016).

The design of any forest accountancy data network has to reflect the specific goals as well as the respective framework conditions. Consequently, compliance with existing systems or standards may only be achieved to varying degrees even in the case of where a new network is to be established. In this sense, the 'Guidelines for Establishing Farm Forestry Accountancy Networks' are not conceived as fixed standards, but as recommendations based on experience (Brandl and Nain 1999; Niskanen and Sekot 2001). Information on alternatives and variation possibilities emphasize that only assistance, but by no means standardization, is intended. This makes a detailed documentation available to interested parties all the more important, so that they can individually assess the degree of compatibility. Otherwise there is the danger of pseudo-harmonization, where the same terms in 
fact refer to different elements. Meta data of the most prominent forest accountancy data networks of the DACH-region were collected in 2004 and supplemented in 2007 (Sekot 2007c) but have not been generally updated since.

\section{Potentials for Internationally Coordinated Research on the Economics of Small-Scale Forestry}

Internationally compatible national documentation systems like the FADN in agriculture would offer ideal possibilities for statistical analyses and for the development and testing of hypotheses especially in regard to national small-scale forestry issues and specific policies. However, there is neither the legal basis nor sufficient political interest for establishing a harmonized research infrastructure and creating a consistent international data pool. So far, also the scientific interest is restricted to networks of bigger forest enterprises (Bürgi et al. 2016). Nevertheless, there is potential for joint research efforts in regard to various aspects of small-scale forestry. Whereas some of the following topics address forest accountancy data networks directly, dealing with others could benefit from such research infrastructure. In the following, some major issues of small-scale forestry and their ties to forest accountancy data networks are addressed.

1. Analysis and improvement of the international comparability of results from forest accountancy data networks. The interfaces and potential links between existing documentation systems are to be identified in terms of methodology as well as in regard to contents. On this basis, international comparisons could be performed and statistical analyses would benefit from larger sample sizes across multiple areas. As specific networks exist in Germany and Austria only, this would be a bilateral exercise in the first place. At least in the long run, this could well serve also as a nucleus for multinational, European initiatives.

2. Operationalization of sustainability of timber production at enterprise and aggregate levels. The assessment of sustainability is especially hampered in small-scale forestry by infrequent harvesting due to the price elasticity of supply to the market (especially significant in Austria Schwarzbauer et al. 2012), the often unsustainable age structure of the growing stock as well as varying cash requirements on behalf of the owner. In contrast to bigger forest enterprises, the allowable cut is hardly significant in regard to harvesting decisions for an individual period. Consequently, it is not to be expected that harvests generally balance with growth increments, at least not in the short run. Long-term monitoring of financial results together with the development of structural characteristics of the forest is a prerequisite for properly addressing the sustainability of timber production.

3. Efficiently overcoming diseconomies of scale in timber production through innovative forms of cooperation. In small forests rational management is difficult to achieve. In many cases, measures remain uncompleted as a result of the lack of labor, machinery or equipment. On the other hand, existing capacities can often not be adequately utilized which may result in considerable idle capacity costs. Especially in combination with the use of the family labor it 
is hard to obtain advantages of scale or specialization. Fixed costs in areas such as forest management planning or certification tend to be prohibitively high for small economic units. Timber marketing suffers from a lack of market knowledge and bargaining power. Last but not least, an optimization of grading is hampered by the tiny volume of resulting assortments. For all of these reasons, the evaluation and further development of various approaches to cooperation constitute a most important challenge. Economic monitoring by means of accountancy networks can provide empirical evidence, which form of cooperation is effective in mitigating these disadvantages.

4. Provision of environmental and recreational services by cooperatives. This may be a task of diversification of the farm economy as far as marketability can be achieved. The demand-oriented provision of public goods and appropriate remuneration systems are another aspect of this topic. In both cases, the provision of ecological or recreational services is established as an additional line of business. Assessing and monitoring the profitability and efficiency of related activities is a promising extension in terms of the scope of forest accountancy data networks.

5. Analysis of the interactions between agriculture and forestry on the farm or regional level. In mixed agricultural and forestry enterprises, the individual lines of business are not independent of each other. Rather, there are interactions in regard to the factors of production involved as well as in financial terms. These generally postulated relationships should be analyzed and quantified in detail as indicated by Brandl and Burgbacher (1985). The rationality of the management decisions on behalf of the farmers should also be scrutinized in such a context.

6. Systematic documentation and characterization of so-called 'new forest owners' Non-farmers, absentee-owners and urban forest owners constitute growing and thus increasingly important categories of forest ownership. In contrast to traditional farm forestry, the new forest owners are a very heterogeneous group with a great variety of basic conditions, goals and needs. From a forest policy perspective, it is of great importance to know this group in more detail and to assess response patterns with respect to any kind of incentive as well as the supply of information and various services. In this context, the 'MOSEFAguidelines' (Niskanen and Sekot 2001) could serve as a starting point for more diversified socio-economic research concepts. These guidelines provide a systematic reference for issues such as sampling, accounting, data management and reporting.

\section{Conclusions and Outlook}

Although the information needs in the context of rural development far exceed the empirical boundaries of any FADN, the focus on agriculture of such monitoring systems will prevail for political, organizational and financial reasons. Hence, there is hardly a potential for statistics on forestry to become part of a systematic 
investigation of the rural economy in Europe. Monitoring the socio-economics of small-scale forestry is thus most likely to remain a task for national or sub-national initiatives. Despite the long common tradition of forest accountancy data networks as instruments of small-scale forest research in Germany and Austria, the respective investigations have remained fragmentary at the national level. New initiatives are typically launched by individual federal states or chambers of forestry at provincial levels. Respective examples in Germany as well as in Austria underpin the potential usefulness of such monitoring systems not only for statistical purposes but also for extension services and policy analyses. Nevertheless, the generally limited, national potential of agricultural accountancy data networks has not even been fully explored yet. As a result, the database for sector statistics remains grossly inadequate in respect to a substantial part of forestry. This deficit is exacerbated by the increasing share of new forest ownership especially as regards small-scale forestry. Given the low level of coordination and cooperation that has been achieved at the national level so far, any institutionalized international networking seems unlikely as does the harmonization of the existing concepts. However, there are quite a number of common challenges for research in small-scale forestry which would benefit from joint efforts. Fostering international cooperation in this field is a responsibility of policy-makers and researchers alike. There is hardly a major issue of regional, national or international forest policy which does not involve the highly fragmented part of the forest sector commonly addressed under the heading of small-scale forestry. The existing forest accountancy data networks in small-scale farm forestry may well serve as a basis for improving and supplementing research in this field.

Acknowledgements Open access funding provided by University of Natural Resources and Life Sciences Vienna (BOKU).

Open Access This article is distributed under the terms of the Creative Commons Attribution 4.0 International License (http://creativecommons.org/licenses/by/4.0/), which permits unrestricted use, distribution, and reproduction in any medium, provided you give appropriate credit to the original author(s) and the source, provide a link to the Creative Commons license, and indicate if changes were made.

\section{References}

Baron U, Hercher W, Nain W, Pistorius T (2001) Testbetriebsnetze der Forstwirtschaft in BadenWürttemberg. (Forest accountancy data networks in Baden-Wuerttemberg) In: Forstwissenschaftliche Fakultät der Universität Freiburg und Forstliche Versuchs- und Forschungsanstalt BadenWürttemberg (eds) Freiburger Forstliche Forschung, no. 34. Freiburg

Brandl H (ed) (1993) Wirtschaftsergebnisse aus dem Privatwald im internationalen Vergleich und angepaßte Forsttechnik für die Bewirtschaftung kleiner Besitzeinheiten. (International comparison of economic results of private forestry and adapted technical solutions for the management of small forests) Mitteilungen der Forstlichen Versuchs- und Forschungsanstalt Baden-Württemberg, no. 176. Freiburg

Brandl H (1998) Zur regionalwirtschaftlichen Bedeutung der Forstwirtschaft im Schwarzwald. (Forestry in the Black Forest in terms of regional economics) In: Sekot W (ed) Beiträge zur Forstökonomik. Schriftenreihe des Instituts für Sozioökonomik der Forst- und Holzwirtschaft no. 31. Wien, pp 69-78

Brandl H (2010) Experiences in collecting data on farm forest enterprises over more than three decades. In: Fakultät für Forst- und Umweltwissenschaften der Universität Freiburg und Forstliche 
Forschungs- und Versuchsanstalt Baden-Württemberg (eds) Berichte Freiburger Forstliche Forschung no. 84. Freiburg, pp 17-25

Brandl H, Burgbacher H (1985) Struktur und wirtschaftliche Bedeutung des bäuerlichen Waldbesitzes in Baden-Württemberg und im Schwarzwald. (Structure and economic significance of farm forestry in Baden-Wuerttemberg and the Black Forest) Mitteilungen der Forstlichen Versuchs- und Forschungsanstalt Baden-Württemberg, no. 118. Freiburg

Brandl H, Nain W (1999) Requirements of the MOSEFA guidelines and the experiences in BadenWürttemberg. In: Niskanen A, Hyttinen P (eds) Prospects of international statistics on farm forestry. EFI proceedings no. 31. European Forest Institute, Joensuu, pp 97-103

Brandl H, Hercher W, Löbell E, Nain W, Olischläger T, Wicht-Lückge G (1999) 20 Jahre Testbetriebsnetz Kleinprivatwald in Baden-Württemberg. (20 years of investigating small-scale forestry in Baden-Wuerttemberg) In: Forstwissenschaftliche Fakultät der Universität Freiburg und Forstliche Versuchs- und Forschungsanstalt Baden-Württemberg (eds) Berichte Freiburger Forstliche Forschung, no. 14. Freiburg

Brenner H (2010) Analyses for the improvement of economic monitoring of Austria's small scale forestry (in German). Master thesis, University of Natural Resources and Life Sciences, Vienna

Bundesministerium für Land- und Forstwirtschaft, Umwelt und Wasserwirtschaft (BMLFUW) (ed) (2009) Einkommensermittlung für den Grünen Bericht, Methodenbeschreibung, Version 2009. (Guidelines for establishing the agricultural income in the context of the "Green Report") Wien

Bundesministerium für Land- und Forstwirtschaft, Umwelt und Wasserwirtschaft (BMLFUW) (ed) (2016) Grüner Bericht 2016 (Green Report 2016). Wien

Bürgi P, Sekot W, Ermisch N, Pauli B, Möhring B, Toscani P (2016) Forest enterprise key figure comparison Germany-Austria-Switzerland (in German). Schweiz Z Forstwes 167(2):73-81

Dieter M (2007) Nutzung von Testbetriebsnetzdaten für gesamtwirtschaftliche Rechnungssysteme. (Utilizing the data out of accountancy networks for national accounting) Fakultät für Forst- und Umweltwissenschaften der Universität Freiburg und Forstliche Forschungs- und Versuchsanstalt Baden-Württemberg (eds) Berichte Freiburger Forstliche Forschung no. 74. Freiburg, pp 75-82

European Communities (eds) (2000) Manual on the economic accounts for Agriculture and Forestry EAA/EAF 97 (Rev.1.1). Office for Official Publications of the European Communities, Luxemburg

Forest Europe, UNECE, FAO (eds) (2011) State of Europe's Forests 2011. Status and trends in sustainable forest management in Europe. Ministerial Conference on the Protection of Forests in Europe, Liaison Unit, Oslo

Hartebrodt C, Aichholz R, Braasch M (2010) Analysing and predicting accountancy network variables with Bayesian belief networks in comparison with traditional analysing methods. In: Fakultät für Forst- und Umweltwissenschaften der Universität Freiburg und Forstliche Forschungs- und Versuchsanstalt Baden-Württemberg (eds) Berichte Freiburger Forstliche Forschung no. 84. Freiburg, pp 57-71

Hogl K, Pregernig M, Weiss G (2005) What is new about new forest owners? A typology of private forest owners in Austria. Small Scale Econ Manag Policy 4 3:325-342

Hufnagl N (1999) The value of socio-economic data collection: forest owner's viewpoint. In: Niskanen A, Hyttinen $\mathrm{P}$ (eds) Prospects of international statistics on farm forestry. EFI proceedings no. 31. European Forest Institute, Joensuu, pp 61-65

Hyttinen P, Kallio T (eds) (1998a) Sampling schemes for monitoring the socio-economics of farm forestry. EFI proceedings no. 28. European Forest Institute, Joensuu

Hyttinen P, Kallio T (eds) (1998b) Cost accountancy in European farm forest enterprises. EFI proceedings no. 20. European Forest Institute, Joensuu

Hyttinen P, Kallio T, Olischläger T, Sekot W, Winterbourne J (1997) Monitoring forestry costs and revenues in selected European countries. European Forest Institute, Research Report 7, Joensuu

LBG Österreich GmbH (ed) (2016) Betriebswirtschaftliche Auswertung der Aufzeichnungen freiwillig buchführender Betriebe in Österreich 2015. (Results derived from voluntary book-keeping in Austria in 2015) Wien

Marongiu S, Cesaro L, Florian D, Tarasconi L (2012) The use of FADN accounting system to measure the profitability of forestry sector. L'Ital For Mont 67(3):253-261. doi:10.4129/ifm.2012.3.03

Nain W (1998) Country reports on farm forestry as a part of the national FADN System in different countries: Germany. In: Hyttinen P, Kallio T (eds) Sampling schemes for monitoring the socioeconomics of farm forestry. EFI proceedings no. 28. European Forest Institute, Joensuu, pp 143-146

Niskanen A, Sekot W (eds) (2001) Guidelines for establishing farm forestry accountancy networks: MOSEFA. European Forest Institute Research Report 12, Brill. Leiden-Boston-Köln 
Olischläger T (1993) Profitability in small scale forestry: an attempt to compare figures from Austria, Baden-Württemberg, Finland and Japan for 1987/1988. In: Simpson C (ed) Proceedings of IUFRO symposium WP 6.11-02 19.-24.9.1993 in Fredericton, pp 161-176

Rebernig B (2006) Comparison of Grüner Bericht and FADN: analysis of the differences in the results of measures of farm income (in German). Master thesis, University of Natural Resources and Life Sciences, Vienna

Rochot A (1984) La comptabilité forestière dans huit pays de l'Europe de l'ouest. (Forestry accounting in eight countries of western Europe) Institut Nationale de la Recherche Agronomique, Nancy

Schwarzbauer P, Huber W, Stern T, Koch S (2012) The timber supply behavior of Austrian forestry in regard to changing frame conditions-an econometric analysis (in German). Allg Forst Jagdztg 138 $3(4): 45-55$

Sekot W (2000) Forest accountancy data networks from a scientific point of view (in German). Allg Forst Jagdztg 171 9(10):170-177

Sekot W (2006) Die bäuerliche Waldwirtschaft im Spiegel von Testbetriebsnetzen. (Farm forestry as documented by accountancy networks) In: Darnhofer I, Wytrzens H-K, Walla Ch (eds) Alternative Strategien für die Landwirtschaft. Facultas, Wien, pp 35-49

Sekot W (2007a) European forest accounting — general concepts and Austrian experiences. Eur J For Res 126(4):481-494

Sekot W (2007b) Stichprobendynamik als methodisches Problem von Testbetriebsnetzen. (Fluctuations of the sample as a methodological problem of accountancy networks) In: Fakultät für Forst- und Umweltwissenschaften der Universität Freiburg und Forstliche Forschungs- und Versuchsanstalt Baden-Württemberg (eds) Berichte Freiburger Forstliche Forschung no. 74, pp 41-52

Sekot W (ed) (2007c) Testbetriebsnetze für den Betriebsvergleich (Accountancy networks for interfirm comparisons). Materials and documentation of the international workshop in Gmunden (A), 08-112007-09-11-2007

Sekot W (2011) Assessing the sustainability of small scale forestry in Austria by means of regional levels of allowable cut (in German). Centralblatt für das gesamte Forstwesen 128(4):195-218

Sekot W, Fillbrandt T, Zesiger A (2011) Improving the international compatibility of accountancy data: the DACH'-initiative. Small Scale For 10(2):255-269

Stridsberg E, Algvere K (eds) (1967) Cost studies in European forestry. Studia Forestalia Suecica no. 49. Skogshögskolan, Stockholm

Toscani P, Sekot W (2014) Austrian farm accountancy data network. In: Schiberna E, Stark M (eds) Adaptation in forest management under changing framework conditions. Proceedings, IUFROsymposium 19-23 May 2014, Sopron, Hungary. Foundation of sustainable forest management, Sopron, pp 221-233

Toscani P, Sekot W (2015) Assessing the economy of small scale farm forestry at the national scale: the case of Austria. Small Scale For. doi:10.1007/s11842-015-9286-x

Weiss G, Hogl K, Rametsteiner E, Sekot W (2007) Private forest property in Austria-newly discovered (in German). Schweiz Z Forstwes 158(9):293-301 